\title{
PENGELOLAAN KELENGKAPAN DOKUMEN DAN PELAYANAN BERBASIS WEB DI DESA SUKAWANGI
}

\author{
Hasbu Naim Syaddad \\ Program Studi Teknik Informatika \\ Universitas Suryakancana \\ hasbunaimsyaddad@unsur.ac.id
}

\author{
Riska Ayu Dastari \\ Program Studi Teknik Informatika \\ Universitas Suryakancana \\ Riska.ayu242@gmail.com
}

\begin{abstract}
Sukawangi Village is a village located in Warungkondang District, Cianjur Regency, West Java Province. At present the management of incoming and outgoing mail still uses a manual system, for archiving it is still not arranged according to the type and number of the letter. Seeing these conditions there must be a software to manage and store incoming mail data and outgoing mail so that it is arranged according to the type and number of the letter. To search the archive in and out the secretary only needs to enter the type or letter number in the search column, with that way it will shorten the time in the search process of the archive. This needs to be done to improve the process performance of entering incoming mail and outgoing mail as well as the results in the form of archives that will be stored in the database. The Document Completion and Web-Based Services Management System in Sukawangi Village uses a prototype model paradigm with UML (unified modeling language) with tools used to design namely usecase diagrams, activity diagrams, class diagram state diagrams and sequence diagrams. While the database application development tool uses PhpMyAdmin. The system designed has the advantage of managing incoming and outgoing mail and in filing incoming and outgoing letters more effectively and efficiently.
\end{abstract}

Keywords: Web, managing incoming mail, managing outgoing mail, incoming mail files and outgoing mail files.

\begin{abstract}
Abstrak
Desa Sukawangi adalah sebuah desa yang berada di Kecamatan Warungkondang Kabupaten Cianjur Provinsi Jawa Barat.Saat ini pengelolaan surat masuk dan surat keluar masih menggunakan sistem manual, untuk pengarsipannya pun masih belum tersusun sesuai dengan jenis dan nomor suratnya. Melihat kondisi tersebut perlu adanya sistem yang menggunakan database untuk mengelola dan menyimpan data surat masuk dan surat keluar agar tersusun sesuai jenis dan nomor suratnya. Untuk pencarian arsip masuk dan keluar sekretaris hanya perlu memasukkan jenis atau nomor surat di kolom pencarian, dengan seperti itu maka akan merpersingkat waktu dalam proses pencarian arsip. Hal ini perlu dilakukan untuk meningkatkan kinerja proses memasukkan data surat masuk dan surat keluar serta hasilnya berupa arsip yang akan disimpan didalam database. Sistem Pengelolaan Kelengkapan Dokumen dan Pelayanan Berbasis Web di Desa Sukawangi menggunakan paradigma model prototype dengan UML (unified modeling language) dengan alat yang digunakan untuk merancang yaitu usecase diagram, activity diagram, class diagram state diagram dan sequence diagram. Sedangkan alat pembangunan aplikasi database menggunakan PhpMyAdmin. Sistem yang dirancang mempunyai kelebihan dalam mengelola surat masuk dan surat keluar serta dalam pengarsipan surat masuk dan surat keluar menjadi lebih efektif dan efisien.
\end{abstract}

Kata Kunci :Web, pengelolaan surat masuk, pengelolaan surat keluar, arsip surat masuk dan arsip surat keluar. 


\section{Pendahuluan}

Desa merupakan bentuk pemerintahan terkecil atau Instansi terkecil dari seluruh Instansi yang ada di Indonesia. Terdapat banyak desa di Indonesia termasuk di Provinsi Jawa Barat, Kabupaten Cianjur. Salah satunya adalah Desa Sukawangi yang terletak di Kabupaten Cianjur, Kecamatan Warungkondang.

Salah satu sarana penting di desa adalah surat karena banyak informasi penting yang terkandung di dalamnya, sehingga diperlukan pelayanan dan pengelolaan yang tepat, serta penyimpanan arsip surat yang baik. Salah satu permasalahan utama adalah bagaimana mengolah data sesuai dengan kebutuhan penduduk. Sampai akhirnya menghasilkan suatu informasi yang berguna dan mudah digunakan oleh pengguna Informasi.

Di Desa Sukawangi terdapat kesulitan dalam pengelolaan menerima dan menyimpan berbagai dokumen khususnya surat masuk dan keluar. Bagian Sekertaris Desa adalah Unit kerja yang mengelolah arsiparsip sebagai hasil akhir dari kegiatan mengolah dan melayani dokumen seperti berkas-berkas surat. Penyimpanan berkas ini belum dilakukan secara elektronik dan terkomputerisasi.

Penggunaan media elektronik diharapkan dapat membantu pihak pengelola dan pelayanan Desa Sukawangi secara efektif dan efisien. Dengan menggunakan media elektronik dalam pengelolaan dan pelayanan dokumen akan lebih cepat, mudah dan hemat dari segi waktu, tenaga dan biaya.

Mengingat begitu pentingnya dokumen bagi sebuah instansi khususnya desa, dimana nantinya arsip surat masuk dan keluar tersebut akan digunakan untuk menyimpan dokumen yang lama maupun yang baru agar tidak hilang dalam bentuk softcopy atau dokumen hasil scan, maka untuk itu perlu dibangun e-document yang dapat menyimpan dokumen secara digital tanpa harus menggunakan tempat yang luas untuk penyimpanan, dan juga dapat memudahkan setiap bagian perangkat desa untuk mencari dokumen serta membantu pegawai dalam mengelola dokumen tersebut.

\section{Landasan Teori}

\subsection{Pengelolaan}

Menurut Balderton (dalam buku Adisasmita, 2011), istilah pengelolaan sama dengan manajemen yaitu menggerakan, mengorganisasikan, dan mengarahkan usaha manusia untuk memanfaatkan secara efektif material dan fasilitas untuk mencapai suatu tujuan.

\subsection{Dokumen}

Menurut Wikipedia, Dokumen atau sahifah adalah sebuah tulisan yang memuat informasi. Biasanya, dokumen ditulis di kertas dan informasinya ditulis memakai tinta baik memakai tangan atau memakai media elektronik (seperti printer).

\subsection{Pelayanan}

Menurut Kamus Besar Bahasa Indonesia (KBBI) adalah sebagai suatuusaha untuk membantu menyiapkan atau mengurus apa yang diperlukan orang lain. Sedangkan menurut Moenir (2010) pelayanan dapat diartikan sebagai kegiatan yang dilakukan oleh seseorang atau kelompok dengan landasan faktor materi melalui sistem, prosedur dan metode tertentu dalam rangka usaha memenuhi kepentingan orang lain sesuai dengan haknya. Pelayanan pada hakikatnya adalah sekumpulan kegiatan, berdasarkan hal tersebut pelayanan merupakan sebuah proses. Sebagai proses, pelayanan berlangsung secara rutin dan berkesinambungan, meliputi seluruh kehidupan orang dalam masyarakat.

\subsection{Pelayanan Desa}

Bentuk pelayanan pemerintah desa kepada masyarakat di Desa Sukawangi Kecamatan Warungkondang Kabupaten Cianjur yaitu apabila masyarakat yang bersangkutan membutuhkan pelayanan seperti :

a. Pelayanan surat pengantar kelakuan baik

b. Pelayanan surat permohonan pindah atau ijin tinggal.

c. Pelayanan surat kuasa penduduk desa

d. Pelayanan surat keterangan tidak mampu.

e. Pelayanan surat kematian.

f. Pelayanan surat balasan dari desa.

Maka dari itu Desa berupaya semaksimal mungkin untuk memberikan pelayanan terbaik kepada warganya. 


\subsection{Surat}

Menurut O. Setiawan Djuharie, Suharie, Teddy Sutandi Komaruddin dalam bukunya "Surat Menyurat Serbaguna" mendefinisikan bahwa : "Surat merupakan komunikasi tertulis untuk menyampaikan informasi pernyataan, pesan kepada pihak lain yang mempunyai keperluan kegiatan dengan berbagai pihak tertentu".

\subsection{Surat Masuk}

Surat masuk adalah surat yang diterima dari perusahaan atau instansi lain kepada pihak yang bersangkutan. Surat masuk adalah saran komunikasi tertulis yang diterima dari instansi/lembaga atau perorangan. Dengan definisi yang lain surat masuk juga dapat bermakna semua jenis surat yang diterima dari instansi lain maupun perorangan, baik yang diterima melalui pos maupun yang diterima dari kurir dengan mempergunakan buku pengiriman (Wursanto, 1991). Dokumen yang dikelola dalam surat masuk adalah :

1. Surat pengantar penempatan dinas.

2. Surat tugas dari instansi pemerintah.

3. Surat edaran dari pemerintah pusat.

4. Surat undangan resmi.

5. Proposal.

\subsection{Surat Keluar}

Surat keluar yaitu surat yang dikirim dari pihak instansi, organisasi atau perusahaan yang berisi tentang suatu informasi atau data baik itu perintah, pemberitahuan maupun informasi lainnya kepda pihak yang bersangkutan. Surat keluar adalah surat yang sudah lengkap (bertanggal, bernomor, berstempel dan telah ditandatangani oleh pejabat yang berwenang yang dibuat oleh suatu instansi atau lembaga lain). Dokumen yang dikekola dalam surat keluar adalah :

1. Surat pengantar kelakuan baik.

2. Surat usaha.

3. Surat keterangan.

4. Surat domisili.

5. Surat kawin.

6. Surat keterangan tidak mampu.

7. Surat kelahiran.

8. Surat kematian.

\subsection{Arsip}

Menurut Barthos (2007) arsip dapat diartikan pula sebagai suatu badan (agency) yang melakukan segala kegiatan pencatatan penanganan, penyimpanan dan pemeliharaan suratsurat/warkat-warkat yang mempunyai arti penting baik ke dalam maupun ke luar, baik yang menyangkut soal-soal pemerintahan maupun nonpemeriantahan, dengan menerapkan kebijaksanaan dan sistem tertentu yang dapat dipertanggungjawabkan.

\subsection{Arsip Digital}

Arsip digital adalah arsip yang sudah mengalami proses konversi dari lembaran kertas menjadi bentuk elektronik. Proses perubahan arsip/dokumen dari lembaran kertas menjadi bentuk elektronik disebut alih media. Hasil conversi arsip fisik ke dalam bentuk digital/elektronik disimpan dalam bentuk file-file yang direkam dalam media elektronik seperti Harddisk, CD, DVD dan lain-lain. Penyimpanan filefile ini dilengkapi dengan Database yang akan membentuk suatu sistem arsip elektronik yang meliputi fasilitas pengaturan, pengelompokan dan penamaan file-file hasil alih media.

2.10. Data

Menurut Mulyanto (2009) data didefinisikan sebagai representasi dunia nyata mewakili suatu objek seperti manusia, hewan, peristiwa, konsep, keadaan dan sebagainya yang direkam dalam bentuk angka, huruf, simbol, teks, gambar, bunyi atau kombinasinya. Dengan kata lain, data dapat didefinisikan sebagai fakta yang menggambarkan suatu peristiwa dan kesatuan yang nyata. Data merupakan material atau bahan baku yang belum mempunyai makna atau belum berpengaruh langsung kepada pengguna sehingga perlu diolah untuk dihasilkan sesuatu yang lebih bermakna

\subsection{Paradigma Pengembangan Sistem}

Paradigma pengembangan sistem yang digunakan adalah paradigma prototype model. Kelebihan metode prototype ini salah satunya adalah adanya komunikasi yang baik antara pengembang dan user. Sehingga pengembangan aplikasi menjadi lebih mudah karena pemakai mengetahui apa yang diharapkannya. 


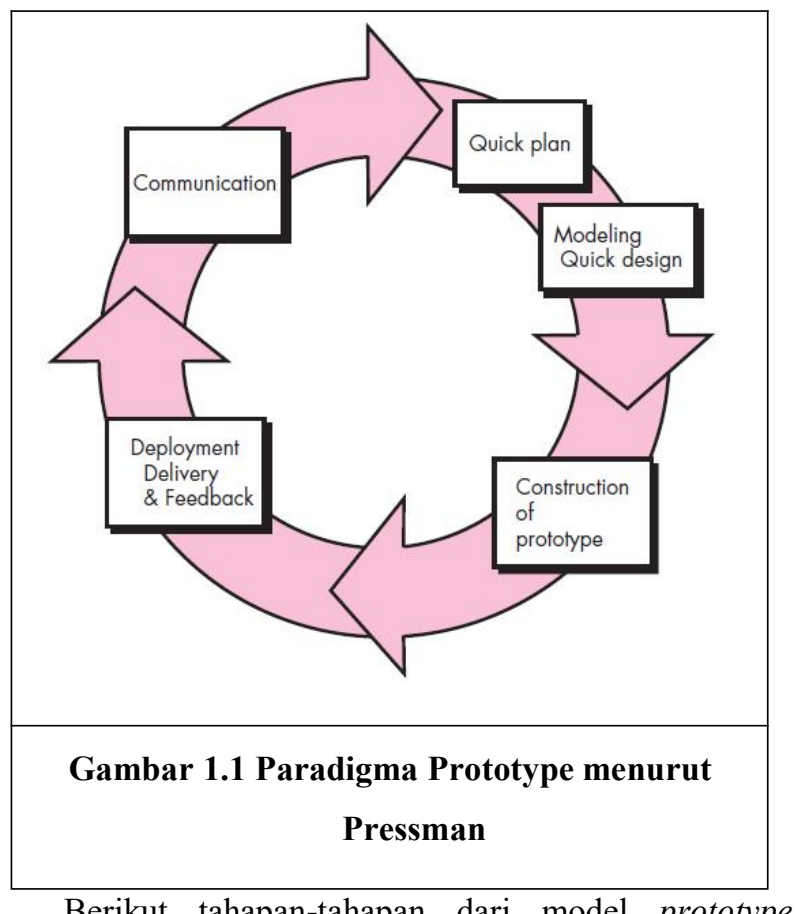

Berikut tahapan-tahapan dari model prototype menurut Pressman:

\section{Communication}

Tahap pertama dari prototype model, dimana tim pengembang melakukan komunikasi dengan pelanggan untuk bersama-sama mendefinisikan format keseluruhan perangkat lunak, mendefinisikan semua kebutuhan, dan garis besar dari sistem yang akan dikembangkan.

2. Quick Plan

Tim pengembang melakukan perencanaan dengan cepat, seperti apa yang akan dilakukan dan pemodelan seperti apa yang akan dibuat.

\section{Modelling Quick Design}

Tim pengembang melakukan pemodelan yang berfokus pada representasi semua perangkat lunak yang akan terlihat oleh para pengguna akhir. Contohnya rancangan antar muka (user interface), selain itu pada tahap ini dimulai konstruksi pembuatan Prototype.

\section{Construction of Prototype}

Tahap pembuatan sistem Prototype, Prototype yang dibuat disesuaikan dengan kebutuhan sistem yang telah didefinisikan sebelumnya dari kebutuhan pelanggan atau pengguna.

5. Deployment Delivery \& Feedback
Pada tahap ini, Prototype dari sistem diuji coba oleh pelanggan atau pengguna. Kemudian dilakukan evaluasi kekurangan-kekurangan dari kebutuhan pelanggan. Tim pengembang kemudian kembali mendengarkan keluhan dari pelanggan untuk memperbaiki Prototype yang ada. ( Sumber : Pressman, 2010).

\subsection{UML (Unified Modeling Language)}

Menurut Nugroho (2010), “UML (Unified Modeling Language) adalah perangkat lunak yang berparadigma "berorientasi objek". Pemodelan (modeling) pada dasarnya dilakukan untuk proses penyederhanaan permasalahan-permasalahan yang kompleks sehingga lebih mudah dipelajari dan dipahami".

\subsection{Visual Paradigm}

Visual Paradigm adalah sebuah aplikasi pemodelan dengan sistem visualisasi yang memungkinkan model yang telah dibuat dapat digunakan sebagai representasi proyek-proyek lain dilengkapi dengan beberapa fitur yang ada didalmnya sampai pada menganalisissebuah proyek yang akan dikerjakan. Diagram dapat disusun sedemikian rupa sehingga dapat dipustakakan menjadi proyek per proyek yang saling berkaitan. Hal ini dapat juga membantu memisahkan terhadap pekerjaan proyek sampai level terkecil.

\section{Analisis Sistem}

\subsection{Diagran UseCase}

Use Case Diagram mendeskripsikan kelakuan sistem dari sudut pandang pengguna, berguna untuk membantu memahami kebutuhan. Use case adalah dasar dari diagram lain. Use case adalah abstraksi dari interaksi antara sistem dan aktor. Use case berkerja dengan mendeskripsikan tipe interaksi antara aktor. 


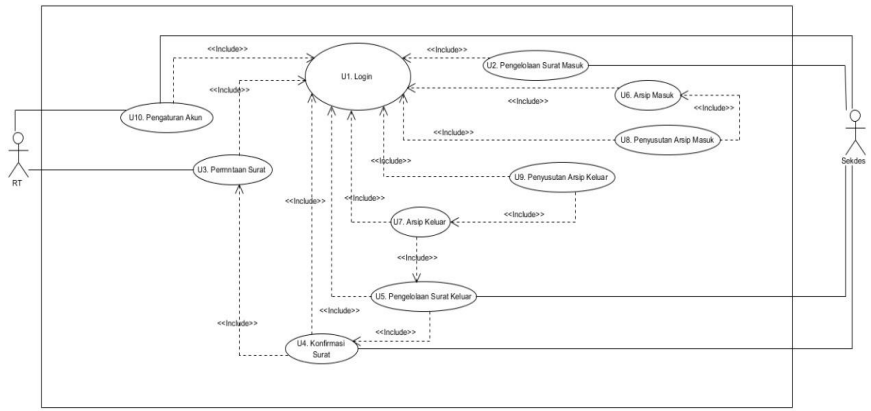

Gambar 3.1 Use Case Diagram Sistem Pengelolaan Kelengkapan Dokumen dan Pelayanan Berbasis Web.

\subsection{Diagran Aktifitas (Swimlane Diagram)}

Swimlane Diagram merupakan diagram yang memperlihatkan aliran aktivitas-aktivitas yang dideskripsikan oleh use case dan pada saat yang bersamaan memperlihatkan aktor mana atau kelas analisa mana yang bertanggung jawab untuk aksi tertentu yang dideskripsikan oleh kotak aktivitas.

a. Login.

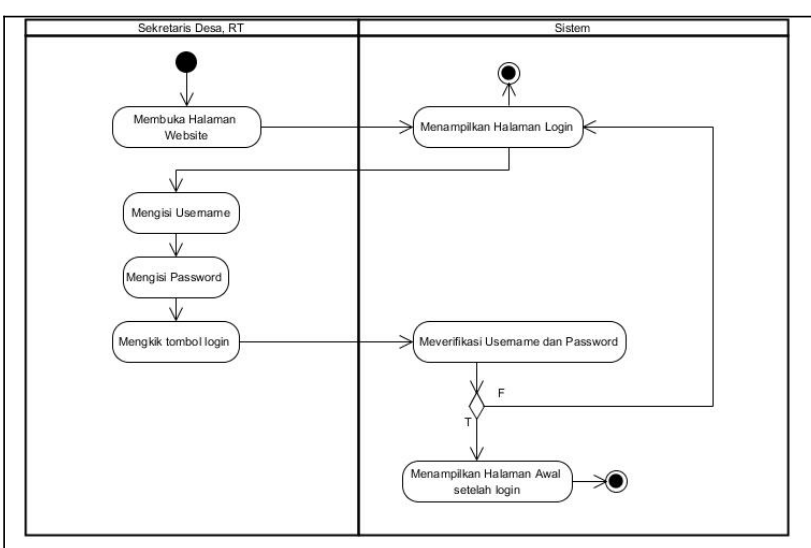

Gambar 3.2 Swimlane Diagram Login.

b. Pengelolaan Surat Masuk.

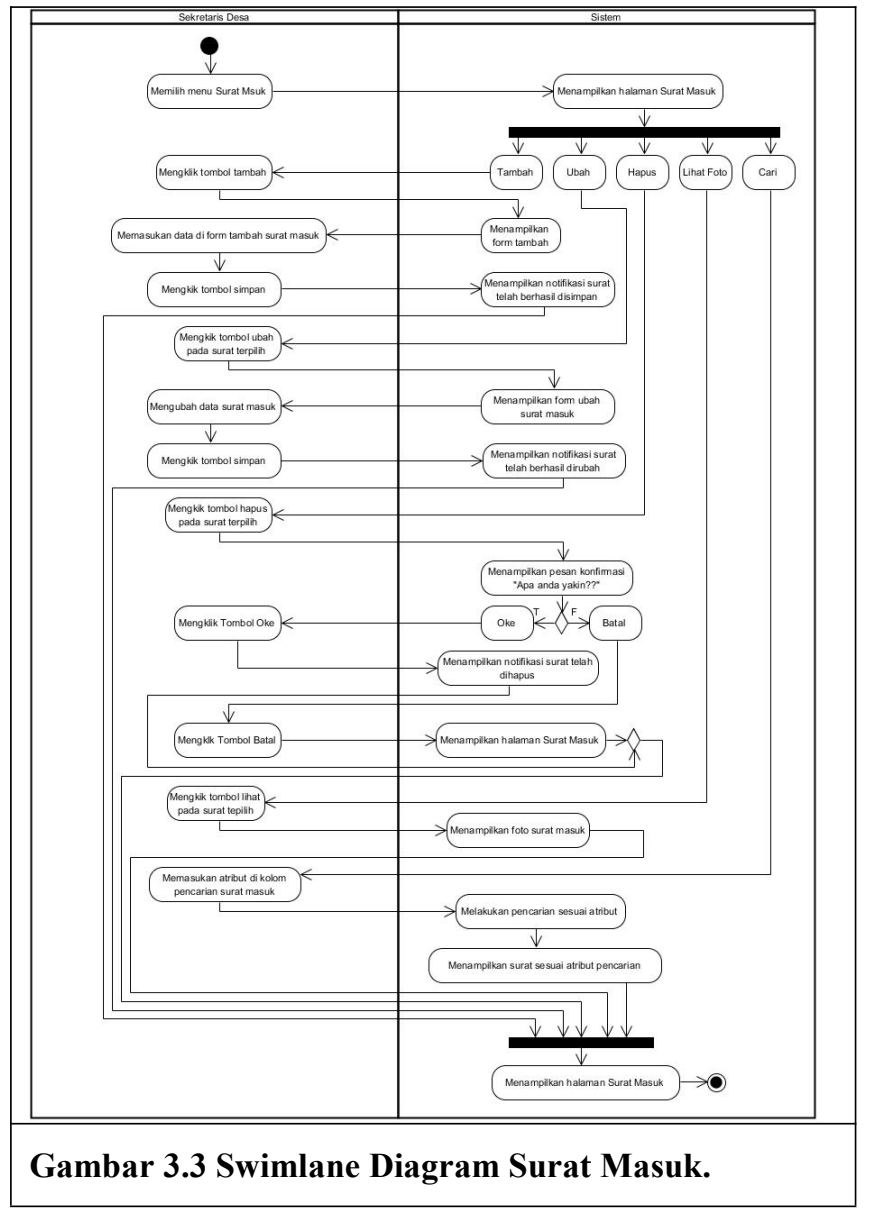

c. Permintaan Surat.

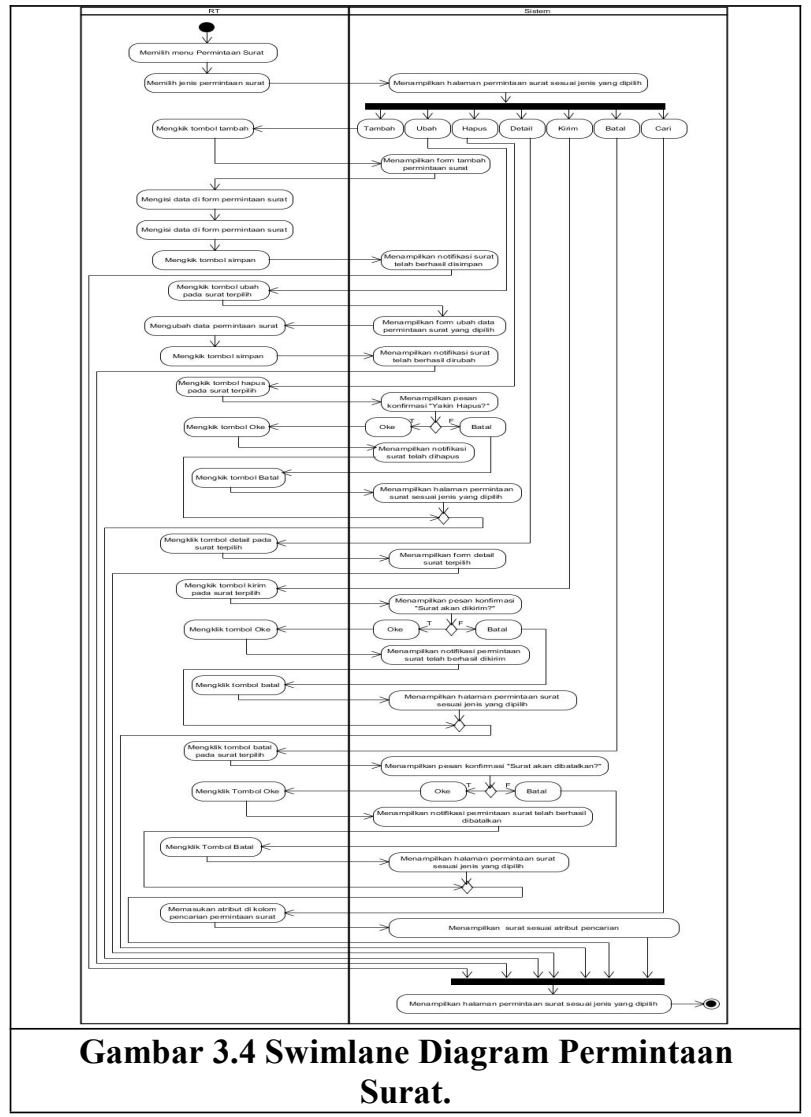


Hasbu Naim Syaddad ${ }^{1}$, Riska Ayu Dastari ${ }^{2}$, Pengelolaan Kelengkapan Dokumen Dan Pelayanan Berbasis Web

Di Desa Sukawangi

d. Konfirmasi Surat.

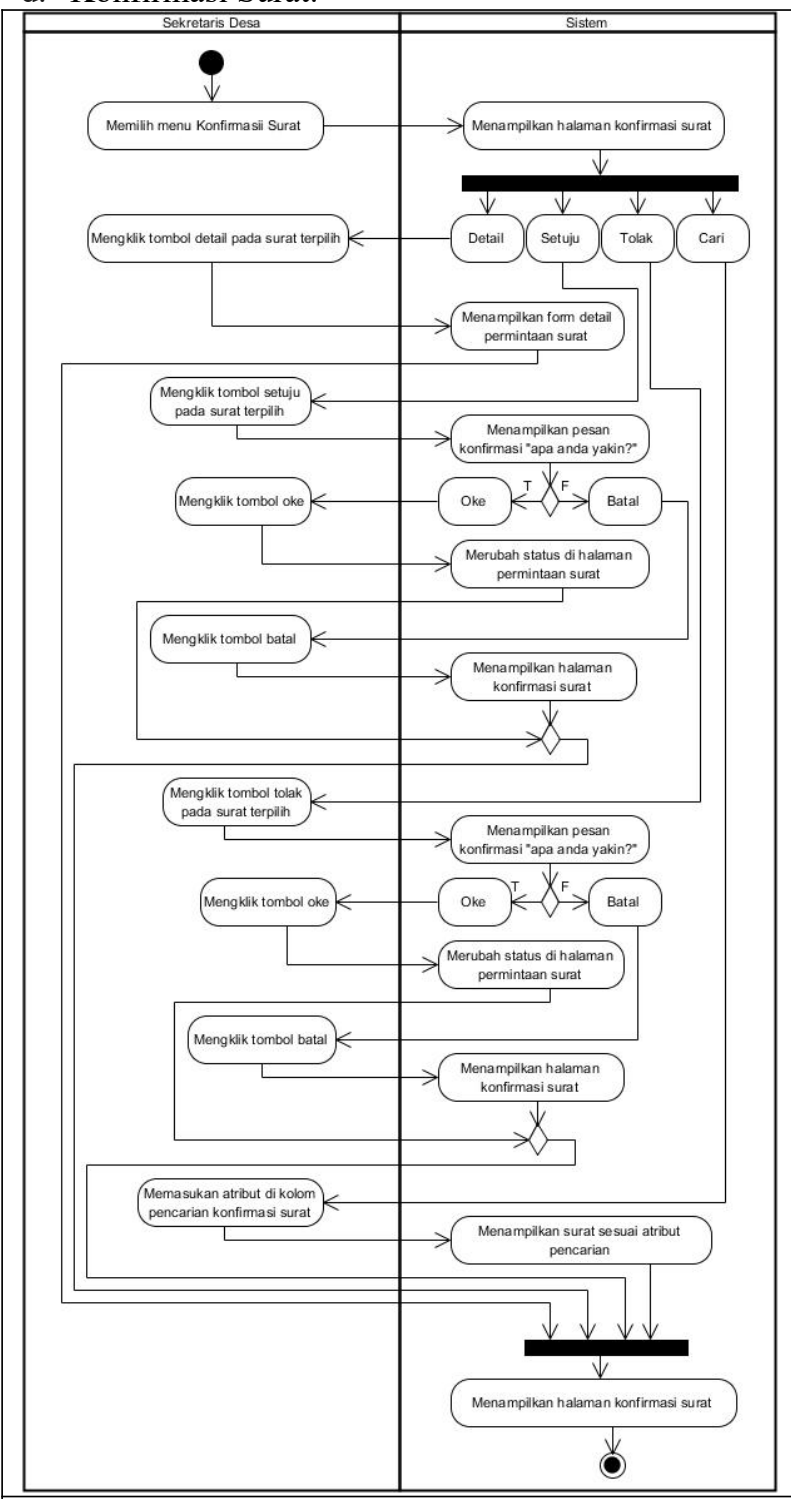

Gambar 3.5 Swimlane Diagram Konfirmasi Surat.

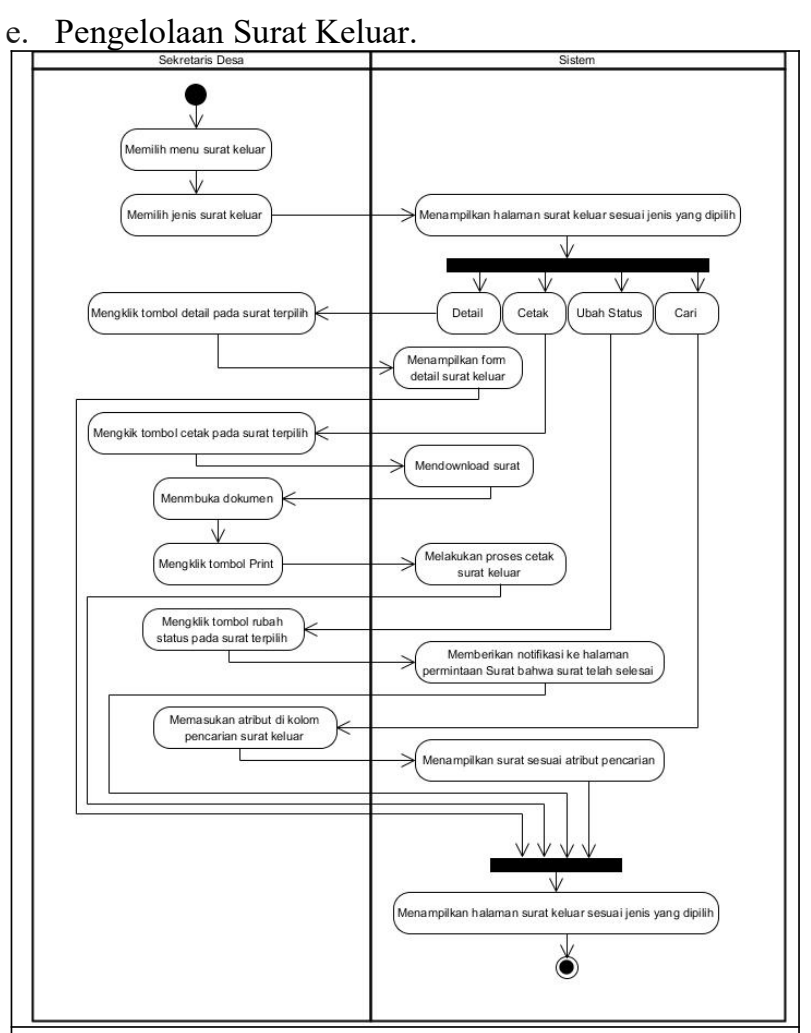

Gambar 3.6 Swimlane Diagram Surat Keluar.

f. Arsip Masuk

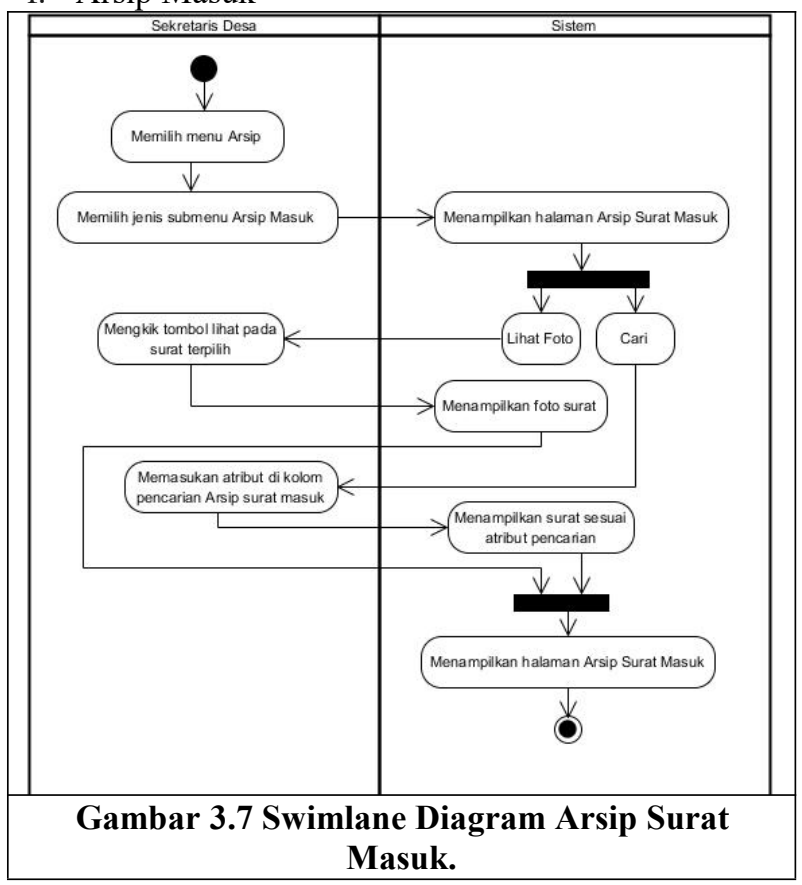


g. Arsip Keluar.

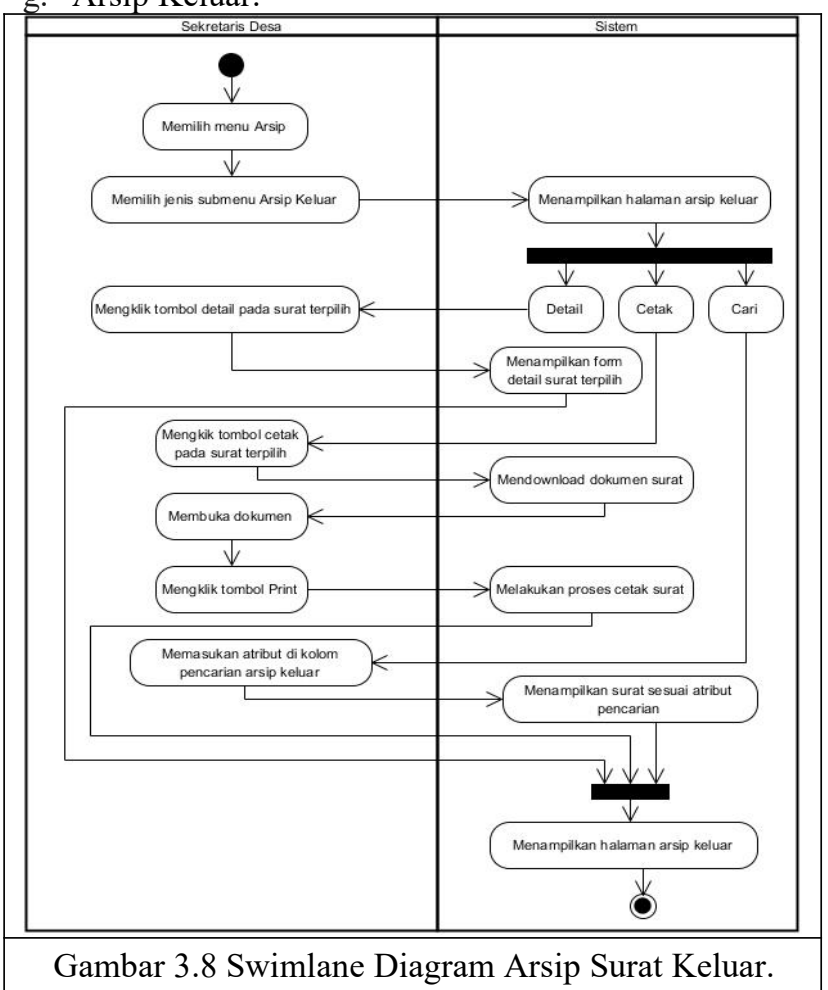

h. Penyusutan Arsip Keluar.

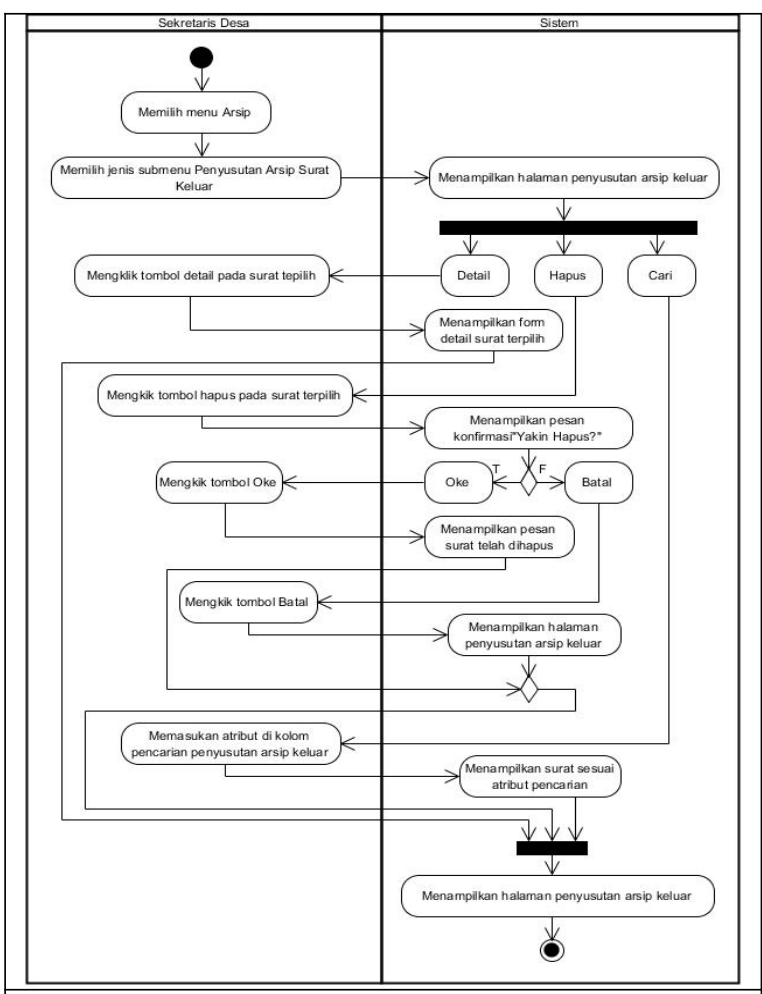

Gambar 3.10 Swimlane Diagram Penyusutan Arsip Surat Keluar. i. Penyusutan Arsip Masuk.

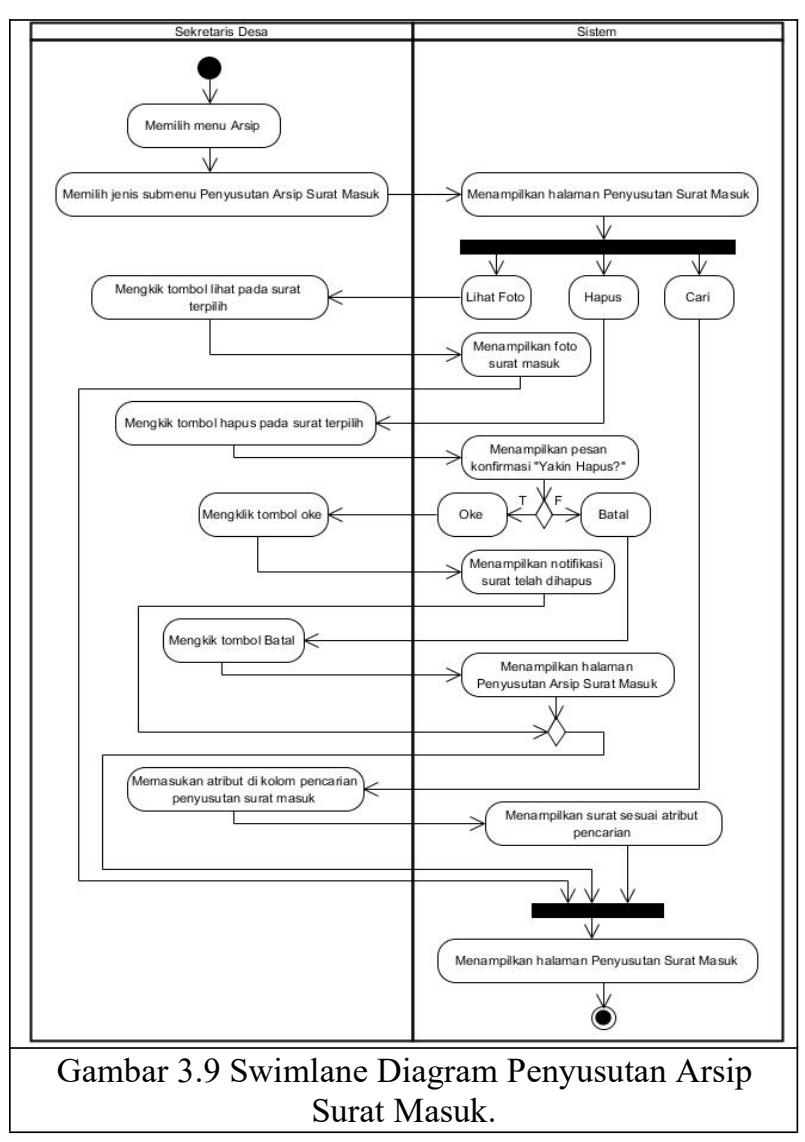

j. Pengaturan Akun.

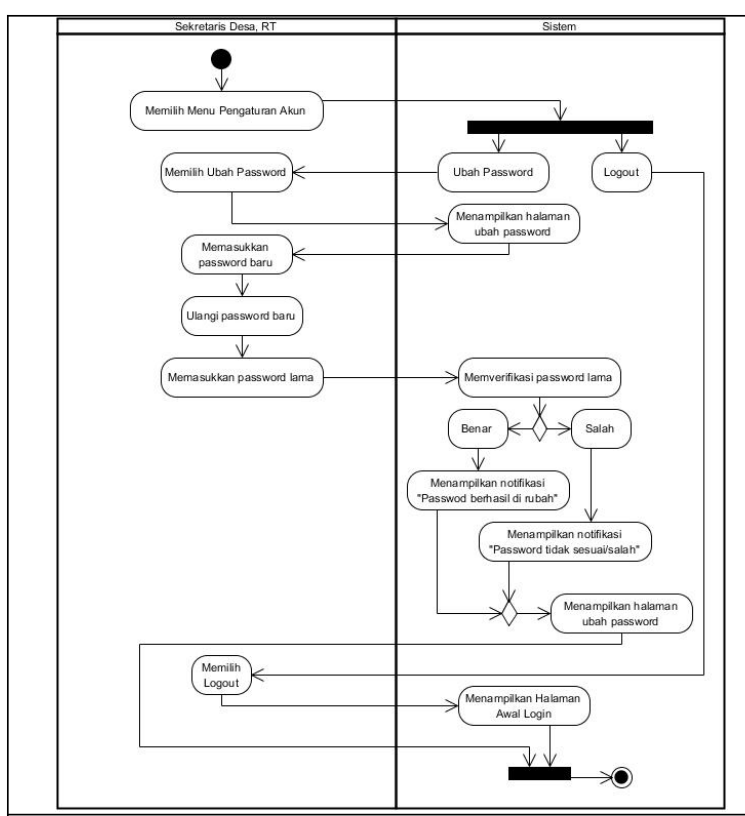

Gambar 3.11 Swimlane Diagram Pengaturan Akun.

\subsection{Diagram Class}

Class Diagram adalah pandangan aplikasi yang statis. Class Diagram tidak hanya menggambarkan visualisasi, menggambarkan dan mendokumentasikan 
aspek yang berbeda dalam sistem, tetapi juga untuk kontruksi eksekusi kode dalam software aplikasi. Class diagram dibuat berdasarkan use case diagram dan activity diagram yang telah dibuat, maka dapat diperoleh kelas-kelas yang digunakan dalam sistem. Class diagram digunakan untuk mengelompokkan hal-hal inti dari setiap proses yang ingin dilakukan. Semua proses dimasukkan ke dalam tiap-tiap class dan saling dihubungkan pada class-class lainnya yang saling berhubungan.

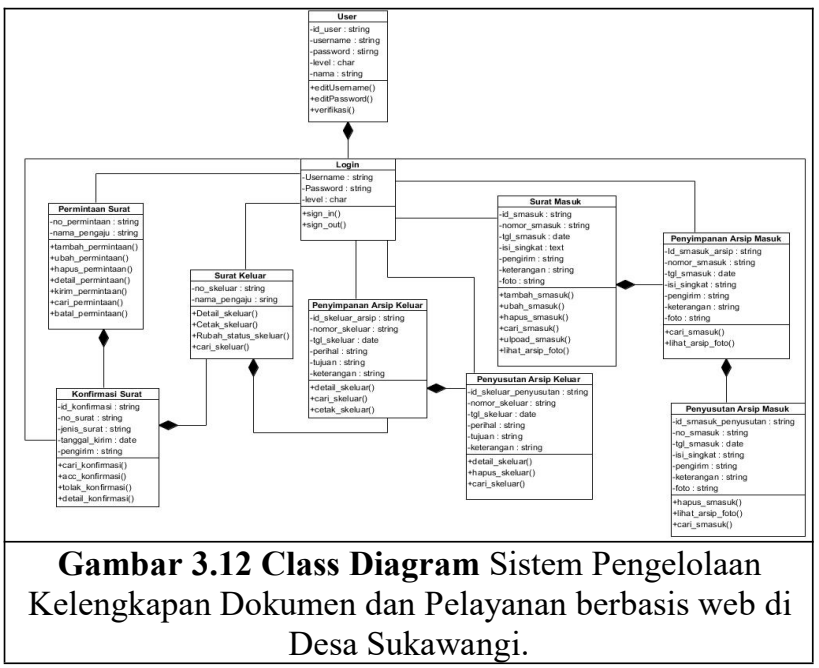

\section{Implementasi}

\subsection{Halaman Login}

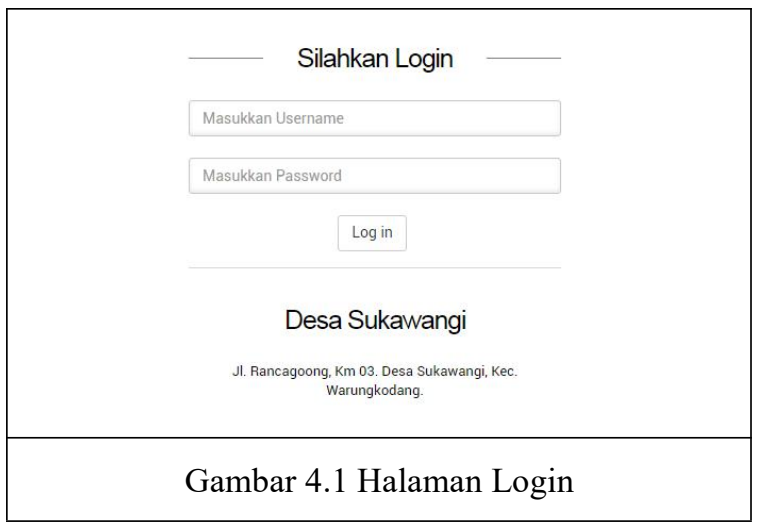

\subsection{Halaman Beranda Sekretaris}

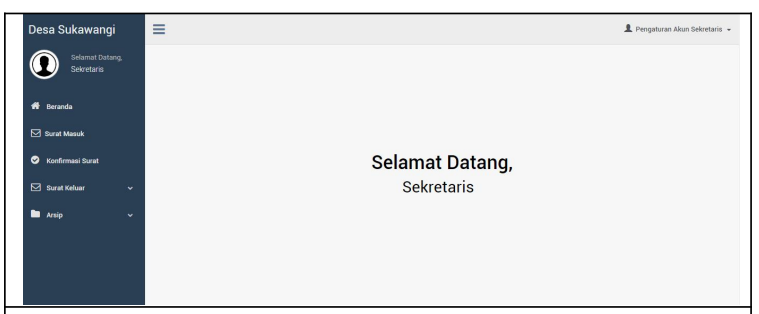

Gambar 4.2 Halaman Beranda Sekretaris

\subsection{Halaman Beranda RT}

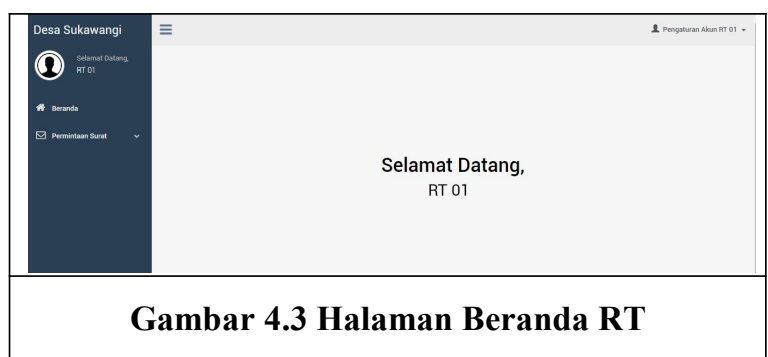

4.4 Halaman Surat Masuk

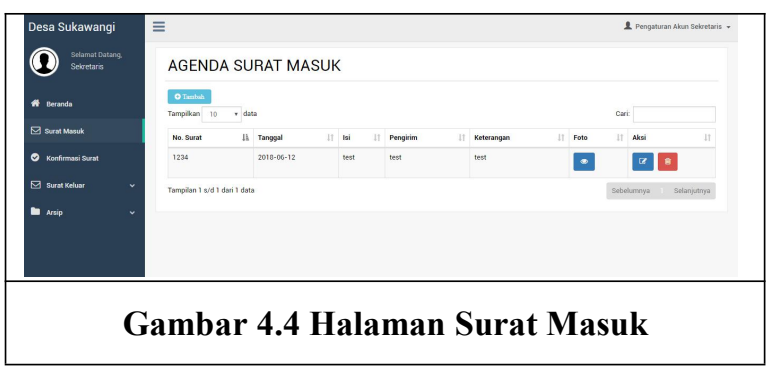

4.5 Halaman Permintaan Surat RT

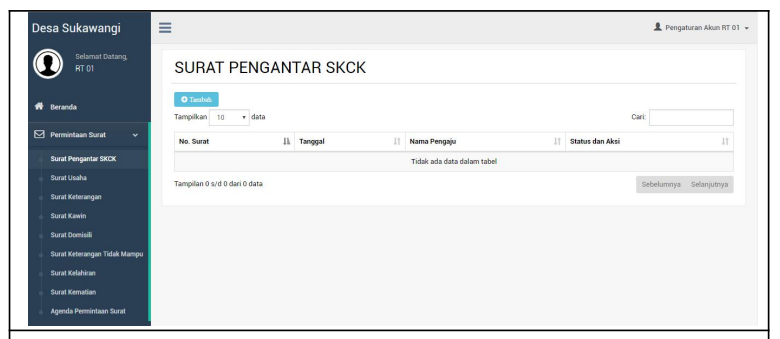

Gambar 4.5 Halaman Permintaan Surat RT

\subsection{Halaman Konfirmasi Surat RT}

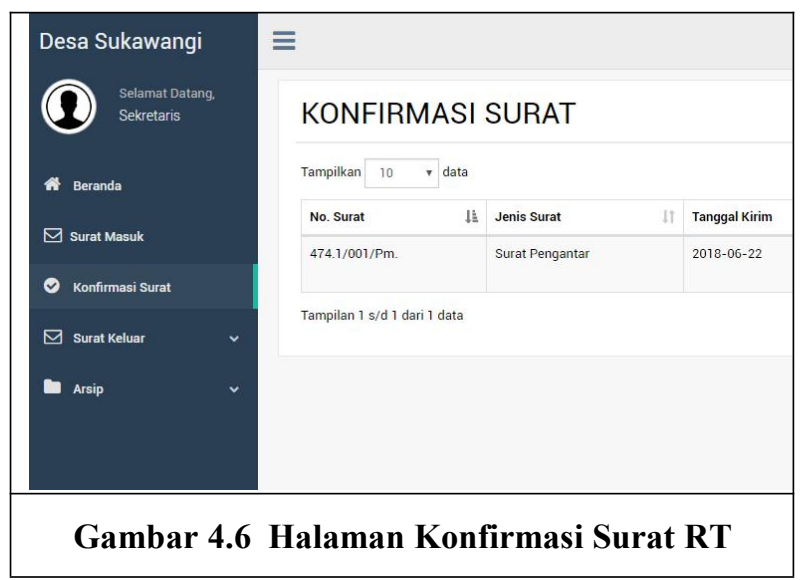




\subsection{Halaman Surat Keluar}

SURAT PENGANTAR SKCK
Gambar Silenanani

\subsection{Halaman Arsip Surat Masuk}

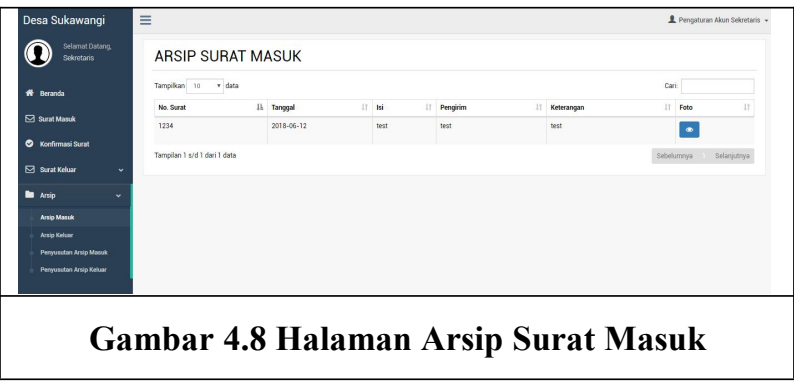

\subsection{Halaman Arsip Surat Keluar}

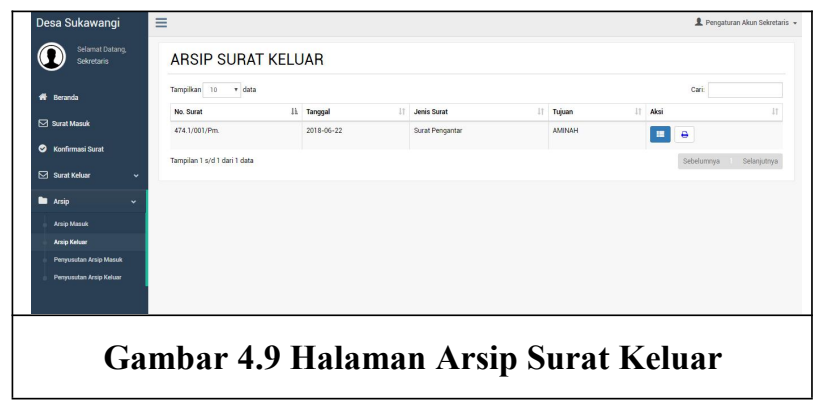

\subsection{Halaman Penyusutan Arsip Masuk}

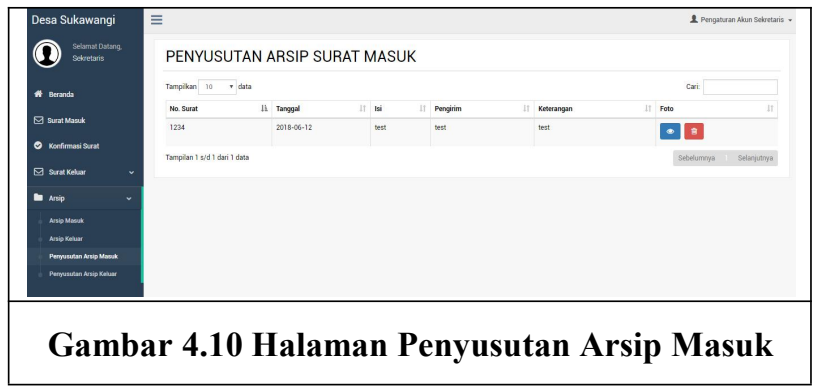

\subsection{Halaman Penyusutan Arsip Keluar}

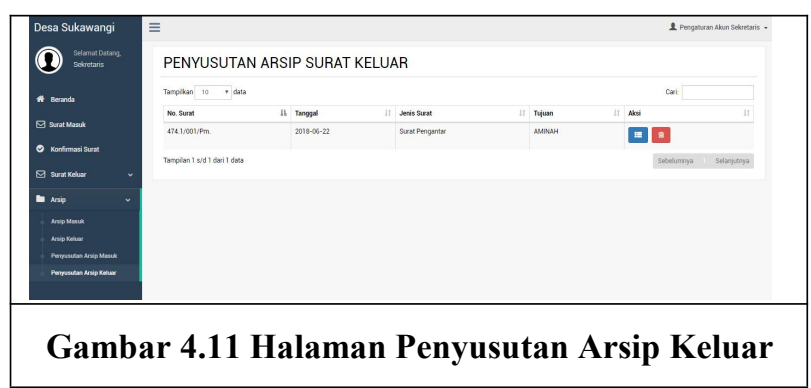

\subsection{Halaman Ubah Password}

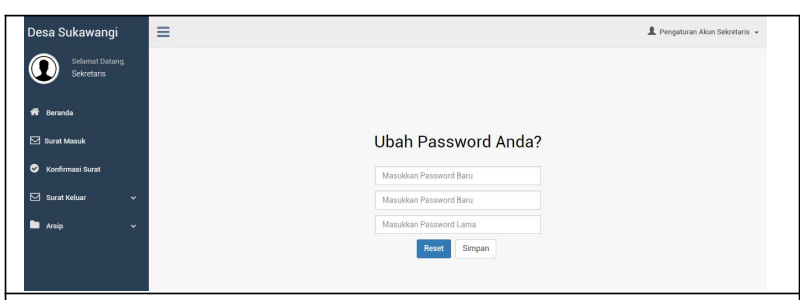

Gambar 4.12 Halaman Ubah Password

\section{Kesimpuan dan Saran}

\subsection{Kesimpulan}

Berdasarkan hasil analisis selama melaksanakan Kerja Praktek di Desa Sukawangi yang berjudul Pengelolaan Kelengkapan Dokumen dan Pelayanan Berbasis Web di Desa Sukawangi, dapat disimpulkan bahwa :

a. Proses pengelolaan dokumen lebih terstruktur.

b. Proses pengelolaan surat keluar yang lebih mudah dengan mengirimkan permintaan surat yang dikirim oleh RT kepada Sekretaris Desa.

c. Pegarsipan surat masuk dan keluar menjadi lebih mudah, dan disimpan ke database.

d. Proses pencarian arsip menjadi efektif dan efisien.

e. Surat masuk dan Surat Keluar lebih tersusun sesuai jenis dan nomor suratnya.

\subsection{Saran}

Untuk meningkatkan kinerja Sistem Pengelolaan Kelengkapan Dokumen dan Pelayanan, maka penulis mengajukan beberapa saran kepada pihak yang akan mengembangkan sebagai pengembang selanjutnya, yaitu dapat dibuatkan sistem yang dapat diakses oleh warganya untuk melihat status surat kependudukan yang diminta. 
6. Daftar Pustaka

[1] Barthos, B. (2007). Manajemen Kearsipan. Jakarta: Bumi Aksara.

[2] Farel. (2018, Februari 28). Pengertian pengumpulan data. Retrieved from Pengertian pengumpulan data: https://farelbae.wordpress.com/catatan-kuliah$\mathrm{ku} /$ pengertian-pengumpulan-data/

[3] M, A. R. (2011). Modul Pembelajaran Rekayasa Perangkat Lunak (Terstruktur dan Berorientasi Objek. Bandung: Modula.

[4] Nugroho, A. (2010). Rekayasa Perangkat Lunak Menggunakan UML dan JAVA. Yogyakarta: Andi Offset.

[5] Pressman, R. S. (2005). Software Engineering: A Practitioner's Approach. New York: McGraw-Hill.

[6] Pressman, R. S. (Software Engineering: A Practitioner's Approach, Fifth Ed.). 2001. New York: McGraw-Hill Book Company.

[7] Syaddad, H. N. (2017). RANCANG BANGUN DIGITAL ARCHIVING DI PERGURUAN TINGGI. Media Jurnal Informatika, 50-51.

[8] Triandini, E. (2012). Step by Step Desain Proyek Menggunakan UML. Yogyakarta: Andi Offset.

[9] Wahyono, A. S. (2005). Manajemen Kearsipan Modern. Yogyakarta: Gava Media.

[10] Wikipedia, E. B. (2018, Februari 13). Dokumen.
Retrieved
from
Wikipedia:

https://id.wikipedia.org/wiki/Dokumen 